Internal exposure to pollutants and body size in Flemish adolescents and adults: Associations and dose-response relationships

Peer-reviewed author version

Dhooge, Willem; Den Hond, Elly; Koppen, Gudrun; BRUCKERS, Liesbeth; Nelen, Vera; Van De Mieroop, Els; Bilau, Maaike; Croes, Kim; Baeyens, Willy; Schoeters, Greet \& Van Larebeke, Nicolas (2010) Internal exposure to pollutants and body size in Flemish adolescents and adults: Associations and dose-response relationships. In: ENVIRONMENT INTERNATIONAL, 36 (4). p. 330-337.

DOI: 10.1016/j.envint.2010.01.005

Handle: http://hdl.handle.net/1942/11065 


\section{Internal exposure to pollutants and body size in Flemish adolescents and adults: associations and dose-response relationships.}

Dhooge Willem $^{1 \mathrm{a}}$, Den Hond Elly ${ }^{2 \mathrm{a}}$, Koppen Gudrun ${ }^{2}$, Bruckers Liesbeth $^{3}$, Nelen Vera $^{4}$, Van De Mieroop $\mathrm{Els}^{4}$, Bilau Maaike ${ }^{5}$, Croes Kim ${ }^{6}$, Baeyens Willy ${ }^{6}$, Schoeters Greet $^{2,7}$, Van Larebeke Nicolas $^{8}$

${ }^{1}$ Department of Endocrinology, Ghent University Hospital, Ghent, Belgium

${ }^{2}$ Environmental Toxicology, Flemish Institute of Technological Research, Mol, Belgium

${ }^{3}$ University of Hasselt, Diepenbeek, Belgium

${ }^{4}$ Provincial Institute of Hygiene, Antwerp, Belgium

${ }^{5}$ Department of Public Health, Ghent University, Ghent, Belgium.

${ }^{6}$ Analytical and Environmental Chemistry (ANCH), Vrije Universiteit Brussel, Brussels, Belgium

${ }^{7}$ University of Antwerp, Antwerp, Belgium

${ }^{8}$ Study Centre for Carcinogenesis and Primary Prevention of Cancer, Department of Radiotherapy, Nuclear Medicine and Experimental Cancerology, Ghent University, Ghent, Belgium.

athese authors have contributed equally

Corresponding author: N. van Larebeke

Tel: +32(0)23801410

Mobile +32(0)475449955

Fax: +(32)(0)2 3811645

E-mail: nicolas.vanlarebeke@ugent.be

Postal Adress: 
N. van Larebeke,

Ninoofse steenweg 379,

B1500 Halle, Belgium. 


\section{Abstract}

Flanders is densely populated with much industry and intensive farming. Body size of 14- to 15-year old adolescents and of adults aged 50-65 was studied in relation to internal exposure to pollutants. 1679 adolescents (887 boys and 792 girls), 775 men and 808 women were selected as a random sample of the population. Concentrations of pollutants in blood or urine were measured in accordance with quality control/quality assurance procedures. Selfassessment questionnaires provided information on personal and life-style factors. Height and weight of subjects were measured. Confounding factors and significant covariates were taken into account. For boys and girls, height and body mass index (BMI) showed a negative association with urinary concentration of cadmium and BMI also with serum concentration of hexachlorobenzene (HCB) and with the sum of serum concentrations of polychlorinated biphenyls (PCBs) 138, 153, and 180 (marker PCBs), whereas BMI showed a positive association with serum concentration of PCB118. For boys, height showed a negative association with urinary concentration of 1-hydroxypyrene (1-OHP) and positive associations with serum concentrations of HCB and PCB118. For adults no significant associations between internal exposure and height were observed. For men, BMI showed negative associations with urinary cadmium concentration and with serum levels of marker PCBs and positive associations with serum levels of $\mathrm{HCB}, \mathrm{p}, \mathrm{p}$ dichlorodiphenyldichloroethylene (p,p'-DDE), PCB118 and the dioxin fraction of dioxinlike activity. For women, BMI showed a negative association with urinary cadmium concentration, with blood lead concentration and with the concentration of marker PCBs in serum, and a positive association with serum concentrations of HCB, p,p'-DDE and PCB118. Associations between biological effects and internal exposures were, in terms of the regression coefficient, often stronger at exposures below the median. Environmental 
exposures to pollutants resulting in "normal" levels of internal exposure were associated with quite substantial differences in body mass index.

\section{Key words:}

lead; cadmium; organochlorines; Polychlorobiphenyls; PCB118; dioxin-like activity;

hexachlorobenzene; p,p'-dichlorodiphenyldichloroethylene; body mass index; height; health effects; low dose. 


\section{Funding}

The study was commissioned, financed and steered by the Ministry of the Flemish Community (Department of Science, Department of Public Health and Department of Environment), without any responsibility for the scientific content.

\section{Approval by Ethical Committee}

The study was approved by the medical-ethical committee of the University of Antwerp on the 4th of July 2002. 


\section{Introduction}

Flanders is one of the most populated areas in Europe, with a dense network of traffic roads, industrial activities and intensive farming close to habitation. The five year (20012006) biomonitoring program on neonates, adolescents and adults (50-65 years) by the Flemish Centre for Environment and Health aimed at measuring internal exposure to pollutants in areas differing in pollution pressure and assessing whether place of residence or observed differences in internal concentrations of pollutants were associated with biological and health effects. All public information on the project can be found on the website www.milieu-en-gezondheid.be.

In this study, we report on body size of 50 to 65 year old adults and 14- to 15-year old adolescents in relation to internal exposure to environmental pollutants suspected to affect hormonal equilibrium. PCBs are known to have estrogenic, anti-estrogenic and antiandrogenic activities (Bonefeld-Jorgensen et al., 2001); p,p'-DDE was reported to have antiandrogenic properties (Kelce et al., 1995); HCB was reported to affect oestradiol levels in animals (Alvarez et al., 2000; Foster et al., 1995) and to interact with hormone receptors (Li et al., 2008); cadmium was observed to be able to interact with both oestrogen and androgen receptors (Stoica et al., 2000; Martin et al., 2002); lead was reported to have xenoestrogenic activity (Martin et al., 2003) and to affect pubertal development in girls (Selevan et al., 2003); polycyclic aromatic hydrocarbons were reported to affect development (Choi et al., 2006) and display as well AhR as estrogen receptor-mediated activity (Hilscherova et al., 2000). We wanted to test the hypothesis that low differences in levels of internal exposure (such as these occurring in the general population in Flanders) to endocrine disrupting substances result in differences in body size parameters. In addition, will this effect be larger at the lower end of the range of measured internal exposures than at the 
higher end of this range? This is what could happen if the above mentioned pollutants interact with receptors, as their dose-response curves might be expected to follow Michaelis -Menten kinetics (Sheehan et al.,1999; Castano et al., 2008). 


\section{Materials and Methods}

\subsection{Selection and recruitment of participants}

Adolescents.

A Stratified Clustered Multi-Stage Design was used to select 1600 participants as a random sample of the adolescents residing in the study areas, comprising $22 \%$ of the Flemish territory, $20 \%$ of the Flemish population and $20 \%$ of the Flemish municipalities as described in detail in Schroijen et al (2008 ). The study areas were chosen to represent different types of environmental pressure occurring in Flanders. Sampling took place in three steps: first by study area, second by entities for access to participants (i.e. the schools), and third by selection of the participants in accordance with the inclusion criteria. The adolescents were enrolled via 42 schools located in the nine selected regions, and sampled between October 2003 and July 2004. For the areas around waste incinerators it was not possible to enroll adolescents through schools, because each separate area around a particular incinerator was small and comprised only a few streets. Therefore, adolescents living near an incinerator received a home addressed letter for participation. Inclusion criteria were: being born in 1988 or 1989, studying in the third year of secondary education, living for at least five years in the same study area, and giving informed consent (both adolescent and parents). Of all pupils who received an invitation, 28,4 \% did not respond, because they did not fulfill the inclusion criteria or because they were not interested, and of those who did respond, $14,7 \%$ refused to participate. So $61,07 \%$ of the pupils contacted wanted to participate. Among the pupils who wanted to participate, $2,3 \%$ were excluded by the researchers because they did not reside in the area since 5 years, and 1,9\% because of 
incomplete questionnaires or insufficient blood or urine. So, finally $58,5 \%$ of the pupils contacted participated in the study. The recruitment resulted in a total of 1679 adolescents.

Adults.

A Stratified Clustered Multi-Stage Design was used to select 775 men and 808 women $(n=1583)$ aged 50 to 65 as a random sample of the population of the areas under study as described by De Coster et al. (2008). Sampling took place in three steps: first by study area, secondly by sub-municipality entities for access to participants, and thirdly by selection of the participants in accordance with the inclusion criteria.

All participants signed an informed consent form and had the right to withdraw from the study at any time. The study design was approved by the medical-ethical committee of the University of Antwerp on July $4^{\text {th }}, 2002$.

\subsection{Blood and urine collection}

Length and body weight of the participants were measured by a study nurse. Each participant donated a urine sample of about $200 \mathrm{~mL}$ and a blood sample of $40 \mathrm{~mL}$ for subsequent analysis. Serum samples were prepared by immediate centrifugation of the coagulated blood. Urine, whole blood and serum samples were fractionated immediately and stored at $-20^{\circ} \mathrm{C}$ until analysis.

\subsection{Measurement of biomarkers of exposure}

Lead and cadmium concentrations in whole blood were determined after an acid digestion pre-treatment destroying the organic matrix and a ten times dilution, followed by high resolution - inductively coupled plasma - mass spectrometry detection (ICP-MS) as 
described by Schroijen et al. (2008). Detection limits for cadmium and lead in the whole blood were 0.09 and $2.0 \mu \mathrm{g} / \mathrm{L}$ respectively for digested blood samples diluted 10 times. Isotope Cd114 was used to quantify the amount of cadmium in urine using ICP-MS. Urinary cadmium levels were expressed in $\mu \mathrm{g} / \mathrm{g}$ creatinine. Urine samples were diluted in nitric acid $(0.7 \%)$. Rhodium was used as an internal standard. The detection limit for urinary cadmium was $0.002 \mu \mathrm{g} / \mathrm{L}$. The creatinine content in urine was determined by spectrophotometry.

Polychlorobiphenyl (PCB) 118, PCB 138, PCB 153, PCB 180, hexachlorobenzene (HCB) and p,p'-dichlorodiphenyldichloroethylene (p,p'-DDE) were measured in serum using gas - chromatography - electron capture detection (GC-ECD) as described by Schroijen et al (2008). The detection limit of all chlorinated compounds in serum was 0.02 $\mu \mathrm{g} / \mathrm{L}$. Blood fat was calculated on the basis of serum cholesterol and serum triglycerides (Covaci et al., 2006). Levels of chlorinated compounds were expressed in ng/g lipid.

CALUX analyses of the dioxin fraction of dioxin-like activity in blood plasma was performed (only in the study on adults) as described by Van Wouwe et al. (2004) and Schroijen et al .(2006). Briefly, $5 \mathrm{~mL}$ of blood plasma was extracted with acetone and $n$ hexane and dried on a Celite/ $\mathrm{Na}_{2} \mathrm{SO}_{4}$ column. The extract was then transferred on an Acid Silica column in series with an activated Carbon column (XCARB column). After elution of the sample with $n$-hexane, the acid silica column was discarded and the XCARB column was then differentially eluted to yield 3 fractions:

1. a mixture of $n$-hexane/acetone allows the elution of some toxic or interfering compounds

2. the PCB fraction is eluted with a mixture of $n$-hexane/toluene/ethyl acetate

3. the fraction with polychlorodibenzodioxins (PCDDs) and polychlorodibenzofurans (PCDFs) is collected with $20 \mathrm{~mL}$ of toluene. 
After this clean-up, fractions 1 and 2 were discarded and only the dioxin fraction was used for the bio-analysis. The solution containing the dioxins was then evaporated and exposed to the mouse hepatoma H1L6.1 cell line developed by Xenobiotic Detection System, Inc. After an exposure time of $20 \mathrm{~h}$, cells were lysed and measurements were made with a luminometer. TEQ-values were calculated after comparison of the obtained signals to a 2,3,7,8-tetrachlorodibenzodioxin calibration curve.

The determination in urine of 1-hydroxypyrene (1-OHP), a metabolite of pyrene, was performed with high performance liquid chromatography (HPLC) as described by Schroijen et al (2008). The detection limit was $0.030 \mu \mathrm{g} / \mathrm{L}$.

$\mathrm{T}, \mathrm{t}$ '-muconic acid ( $\mathrm{t}, \mathrm{t}$ '-MA), a metabolite of benzene, was determined in urine by means of ion chromatography using SPE-SAX columns as described by Schroijen et al (2008). The detection limit was $0.0086 \mathrm{mg} / \mathrm{L}$. Levels of 1-OHP and ttMA were expressed in $\mu \mathrm{g} / \mathrm{g}$ creatinine and $\mathrm{mg} / \mathrm{g}$ creatinine respectively.

All laboratories involved in the analyses of biomarkers applied standard agreed quality control/quality assurance procedures.

\subsection{Measurement of hormone levels}

Commercial immunoassays were used to determine serum levels of total testosterone (T), luteinizing hormone ( $\mathrm{LH})$, follicle stimulating hormone (FSH), sex hormone binding globulin (SHBG;) and total 17ß-estradiol (E2) as described by Croes et al. (2009). The free fractions of T (fT) and E2 (fE2) were calculated from T and SHBG in serum, as described by Croes et al. (2009). The intra- and interassay coefficients of variation for all assays were less than $12 \%$. For each individual, the aromatase index - the ratio of $\mathrm{T}$ on E2 (T/E2)- was calculated as pmol/pmol. Data on hormone levels were, in this publication, only used as 
covariates in some analyses concerning body size. A full report on our observations concerning associations of hormone levels with internal exposure to pollutants is submitted (Dhooge et al., 2009).

\subsection{Questionnaires}

Information on personal and life-style factors and on health status was obtained by self-assessment questionnaires filled in by the participants or, in the case of the adolescents, by the adolescents and by their parents. Information provided by the parents included data on education, weight, height and health status of the parents. Information provided by the participating adults and adolescents included data on health status, contraception, smoking behavior and consumption of alcohol and for the adults also education. For both adolescents and adults "highest education in the family" was used as parameter in statistical analysis. The participants also completed a semi-quantitative food frequency questionnaire concerning daily consumption of fruit and vegetables during the last year, and, as described by Bilau et al. (2008), a semi-quantitative food frequency questionnaire to assess the daily consumption of fat-containing food items during the last year. In addition, the consumption of locally produced food was recorded. On the basis of these questionnaires a number of parameters were calculated, including, for adolescents, consumption in g/day of fresh fruit and vegetables, cereals, fish, dairy products, meat and daily intake of animal fat. For adults also the total consumption of fat in $\mathrm{g} /$ day was calculated. 


\subsection{Data on sexual development.}

Data on growth and sexual development for 767 boys and 636 girls were obtained from the 25 Centers for School Health Examination, where all pupils are examined once every two years by school doctors. All pupils were examined during the school year 20032004. Sexual development was routinely measured through the international score of Marshall and Tanner $(1969,1970)$, on a scale from 1 (start of puberty) to 5 (adult stage). Genital (stages G1 to G5) and pubic hair (P1 to P5) development were assessed in boys; breast (B1 to B5) and pubic hair (P1 to P5) development in girls. Shortly before the biomonitoring study was conducted, all school doctors had received a re-training for the assessment of pubertal development since new Flemish growth curves were developed in the periode 2000-2004 (ref: http://www.vub.ac.be/groeicurven/english.html). Data on sexual development were, in this publication, only used as covariates in some analyses concerning body size. A full report on our observations concerning associations of sexual development with internal exposure to pollutants is submitted (Den Hond et al., submitted).

\subsection{Data treatment}

Database management and statistical analyses, for male adults, female adults, male adolescents and female adolescents separately, were performed with SAS for Windows, version 9.1.3 and Statistica, version 7.1. Data that were not normally distributed were subjected to natural logarithmic transformation for use as dependent variables in Ancova, multiple regression or logistic regression. Geometric means or medians $\left(10^{\text {th }}\right.$ and $90^{\text {th }}$ percentile) are reported. The sum of marker PCBs (PCB138 + PCB153 + PCB180) was 
used to reflect exposure to PCBs in general, whereas the serum concentration of PCB118, considered to reflect exposure to dioxin-like PCBs (Park et al., 2007), was used separately.

Raw data were adjusted by regression analyses for some pre-specified, literature based confounders and also for covariates showing significant association with effect parameters. For adolescents, confounders of data on height and BMI were age, height of father and height of mother. For adults age was considered a confounder for BMI. Adjustment for smoking was performed for adolescents using the parameter "daily smoking or not" and for adults by the number of cigarettes smoked per year. Adjustment for sexual maturation, performed in some analyses, was done through classifying the boys as having reached stage P3 and the girls as having reached stage P4. Additionally, parameters related to food intake and other parameters derived from the questionnaires were included as covariates in multiple linear regression when they showed in simple regression significant association $(\mathrm{p}<0.1)$ with the dependent variable under study.

To evaluate the association of biological effect parameters with parameters of internal exposure after adjustment, if relevant, for other concurrent internal exposures, a series of forward stepwise multiple regressions was performed in which we set the $\mathrm{F}$ value to enter at 1.2 and the F value to stay at 1.1, with the biological effect parameter as dependent variable and as independent variables all predetermined confounders and all parameters related to exposure, food intake, life style or personal characteristics that showed (in simple regressions) significant $(\mathrm{p}<0.1)$ association with the biological effect parameter used as dependent variable. Confounders were forced in the resulting model. For every analysis reported in the tables the list of confounders and covariates included in the model is mentioned.

To assess the strength of the association (in terms of the regression coefficient) in function of the intensity of internal exposure, two additional sets of multiple regressions, 
including confounding factors, were performed: one including only subjects with exposures above the median for a particular pollutant, and one including only subjects with exposures equal to or below the median. To facilitate interpretation of this comparison, the parameter for the particular pollutant under study was used without natural logarithmic transformation. A Piecewise Linear Regression model was used to assess statistical significance of differences in these additional multiple regressions. To assess the strength of association in function of the intensity of internal exposure after correction for other significant covariates or exposures, such additional sets of multiple regressions were also performed including significant covariates in addition to confounding factors and finally also including all covariates and exposure variables present in the models resulting from stepwise regressions. Analysis of residuals was performed after each multiple regression.

For calculation of binomial probability the probability of success on a single trial was set at 0.5 . 


\section{Results}

\subsection{Characteristics of participants, nutritional and other life style factors}

Of the boys ( $\mathrm{n}=887), 14.5 \%$ drank alcoholic beverages at least weekly, $8.2 \%$ smoked daily and $46.6 \%$ lived in a family in which at least one parent had received higher education. Respective data for girls $(n=792)$ were $13.8 \%, 7.7 \%$ and $53.1 \%$. Oral contraception was used by $9.3 \%$ of the girls. Other characteristics of participants are summarized in Table 1a.

Of the adult men, $(n=775), 22.1 \%$ were present smokers and $37.6 \%$ lived in a family in which at least one partner had received higher education. Of the adult women $(n=808)$, $14.4 \%$ were present smokers and $41.1 \%$ lived in a family in which at least one partner had received higher education. Other characteristics of participants are summarized in Table $1 \mathrm{~b}$.

\subsection{Internal exposure to pollutants.}

Data on internal exposure (median values and $10^{\text {th }}$ and 90 th percentiles) to pollutants for boys and girls separately are given in Table 2. For adolescents, exposure data and also differences in function of area of residence are discussed in detail by Schroijen et al. (2008). Levels of lead and organochlorine chemicals were substantially higher in boys than in girls. In boys, following significant $(\mathrm{p}<0.05)$ positive correlations with a Pearson correlation coefficient (r) of at least 0.3 were observed: serum concentration of marker PCBs with serum concentrations of PCB118 $(r=0.52)$ and $\mathrm{HCB}(r=0.45)$; serum concentration of HCB with serum concentration of PCB118 $(r=0.30)$. For girls, following significant positive correlations with a Pearson correlation coefficient of at least 0.3 were observed: 
serum concentration of marker PCBs with serum concentrations of PCB118 $(r=0.65)$ and HCB $(r=0.44)$; serum concentration of HCB with serum concentration of PCB118 $(r=$ $0.43)$.

Data on internal exposure (median values and $10^{\text {th }}$ and 90 th percentiles) to pollutants for adults are given in Table 3. In men following significant $(\mathrm{p}<0.05)$ positive correlations with a Pearson correlation coefficient of at least 0.3 were observed: serum concentration of marker PCBs with serum concentrations of PCB118 $(r=0.69), \mathrm{HCB}(\mathrm{r}=0.43)$ and $\mathrm{p}, \mathrm{p}$ '$\operatorname{DDE}(r=0.39)$; serum concentration of HCB with serum concentrations of $p, p$ '-DDE $(r=$ $0.40)$ and PCB118 $(r=0.44)$; urinary concentration cadmium with blood concentration of cadmium $(r=0.47)$. In women following significant $(\mathrm{p}<0.05)$ positive correlations with a Pearson correlation coefficient of at least 0.3 were observed: serum concentration of marker PCBs with serum concentrations of PCB118 $(r=0.74)$, HCB $(r=0.43)$ and p,p'-DDE $(r=$ 0.50); serum concentrations of HCB with serum concentrations of $\mathrm{p}, \mathrm{p}$ '-DDE $(\mathrm{r}=0.42)$, and PCB118 ( $r=0.49)$; serum concentration of p,p'-DDE with serum concentration of PCB118 $(r=0.48)$; urinary cadmium concentration with blood cadmium concentration $(r=0.44)$.

\subsection{Adolescents :body size in relation to internal exposure to pollutants}

After adjustment for confounders and significant covariates through a series of multiple regressions, each comprising a body size parameter as dependent variable and one parameter of internal exposure among the independent variables, significant associations were found between height or BMI and several parameters of internal exposure. To evaluate the association of height and BMI with parameters of internal exposure after additional adjustment, if relevant, for other concurrent internal exposures, a series of forward stepwise multiple regressions was performed as described under methods. Table 4 shows associations 
that were significant $(\mathrm{p}<0.05)$ in multiple regressions including only one parameter of internal exposure and that still showed the same trend in the stepwise multiple regressions in which all significant parameters of internal exposure were included. In addition the more complex data concerning BMI and PCB118 are included.

Negative associations with height were observed for urinary cadmium (both boys and girls) and 1-OHP (only boys), and these negative associations persisted after additional correction for urinary creatinine. For both boys and girls the associations between levels of urinary cadmium with height were only slightly weakened by adjustment for sexual maturation and remained significant.

Levels of HCB and PCB118 showed a positive association with height in boys. The association with PCB118 was no longer statistically significant after additional adjustment for other parameters of internal exposure, although a positive trend was still observed. As co-linearity between concentrations of PCB118 and HCB (Pearson correlation coefficient = 0.30) might have affected the association between PCB118 and length after this additional adjustment, we performed a stratified analysis testing the association of PCB118 concentration with height after adjustment for covariates and other exposures in 13 strata of HCB concentration. In 9 of these 13 strata a positive association was observed between the concentration of PCB 118 and height (binomial probability $=0.087$ ), and in 2 of these strata the positive association was significant $(\mathrm{p}<0.05)$ whereas in none of the strata the negative association was significant. When testosterone level was included as covariate, the positive association between HCB and height disappeared almost completely, whereas the positive association between PCB 118 and height was also weakened but persisted to a greater extent (data not shown). Whereas the association of HCB level with height in boys lost significance after adjustment for sexual maturation, the association of PCB118 level with height was not weakened at all by adjustment for sexual maturation (data not shown). 
Levels of urinary cadmium, marker PCBs, HCB and p,p'-DDE showed negative associations with BMI for both boys and girls. These negative associations persisted after additional correction for sexual maturation (data not shown).

The negative association of PCB118 with BMI observed in simple regression as well for girls as for boys might be due to the fact that those adolescents having higher PCB118 levels often also had higher marker PCB levels (correlation coefficient 0.52 for boys and 0.65 for girls) and marker PCBs showed a strong negative correlation with BMI. After additional adjustment for other exposures a positive association was observed between PCB118 concentrations and BMI. To confirm this finding we performed a stratified analysis testing the association between PCB118 concentration and BMI after adjustment for covariates and other exposures in 13 strata of marker PCB concentrations for boys and 14 strata of marker PCB concentrations for girls. In 12 of these 13 strata for boys a positive association was observed between the concentration of PCB118 and BMI (binomial probability $=0.0016$ ), and in 2 of these strata the positive association was significant ( $\mathrm{p}<0.05$ ). In 13 of these 14 strata for girls a positive association was observed between the concentration of PCB118 and BMI (binomial probability $=0.0009$ ), and in 2 of these strata the positive association was significant $(\mathrm{p}<0.05)$.

We also studied the strength of association (in terms of the regression coefficient) in function of the intensity of internal exposure. Comparison of the regression coefficients obtained from additional multiple regressions including confounding factors performed as described under methods showed that 10 out of 11 associations of body size parameters with internal exposure (Table 5) tended to be stronger at exposures below the median value than at exposures above the median and this difference was statistically significant $(\mathrm{p}<0.05)$ for 7 of these associations. Additional multiple regressions including, besides confounding factors, also either significant covariates or all covariates and exposures present in the 
models resulting from stepwise regressions, produced similar results: 10 out of 11 associations of hormone levels with internal exposure tended to be stronger at exposures below the median value (data not shown). These differences persisted after additional correction for sexual maturation (data not shown). The association between PCB118 serum concentration and BMI after adjustment for the confounding effect of marker PCBs was also stronger at exposures below the median (data not shown), corroborating the trend for most other associations described here.

\subsection{Adults: body size in relation to internal exposure to pollutants.}

After adjustment for confounders and significant covariates through a series of multiple regressions, each comprising a body size parameter as dependent variable and one parameter of internal exposure among the independent variables, significant associations were found between BMI and several parameters of internal exposure (Table 6). For adults, no significant associations were found between height and internal exposure to the measured pollutants. To evaluate the association of BMI with parameters of internal exposure after additional adjustment, if relevant, for other concurrent internal exposures, a series of forward stepwise multiple regressions was performed as described under methods (Table 6). For men, significant positive associations were observed between BMI and serum concentrations of $\mathrm{HCB}, \mathrm{p}, \mathrm{p}$-DDE, PCB118 and dioxin-like activity which persisted after additional adjustment for concurrent internal exposures. A significant negative association was found between BMI and serum concentration of marker PCBs after adjustment for concurrent internal exposures and between BMI and urinary cadmium concentration, but with regard to urinary cadmium statistical significance was lost after additional adjustment for concurrent internal exposures. For women, BMI showed significant positive associations 
with serum concentrations of $\mathrm{HCB}, \mathrm{p}, \mathrm{p}$ '-DDE and $\mathrm{PCB} 118$ and significant negative associations with serum marker PCB concentration and with urinary cadmium concentration, all of which persisted after additional adjustment for concurrent internal exposures. In addition, a significant negative association was found between BMI and blood lead concentration, but statistical significance was lost after additional adjustment for concurrent internal exposures.

We also studied the strength of association (in terms of the regression coefficient) in function of the intensity of internal exposure. Comparison of the regression coefficients obtained from additional multiple regressions including confounding factors performed as described under methods showed that 11 out of 12 associations of body size parameters with internal exposure (Table 7) tended to be stronger at exposures below the median value than at exposures above the median and this difference was statistically significant $(p<0.05)$ for 7 of these associations. 


\section{Discussion}

Our cross sectional biomonitoring study has certainly limitations in terms of demonstrating causal relationships. Also, the biological parameters under consideration could not only be influenced by exposures and other factors present at the time of the study, but also by such factors acting many years before. Notwithstanding these limitations, several potentially interesting associations were observed. Our understanding of the mechanisms underlying these associations is however incomplete .

Urinary cadmium concentration showed a negative association with height in boys, a negative association with height and BMI in girls and a negative association with BMI for both adult men and women. In boys, the negative association with BMI almost disappeared and lost statistical significance after adjustment for concurrent exposures. That negative associations with height persisted after additional correction for urinary creatinine, suggests that these associations were not simply due to higher creatinine levels in adolescents of greater height. That we found, in the boys participating in this study, also a negative association between urinary cadmium levels and sex hormone levels (Dhooge et al, 2009) suggests that effects on height might result from effects on hormone levels. However, that negative associations with height observed for adolescents persisted after additional correction for sexual maturation suggests that these associations were not solely due to effects on hormone levels and sexual maturation. Cadmium showed, in vitro, toxic effects on the testis (Steinberger and Klinefelter 1993), was found to inhibit the expression of steroidogenic acute regulatory protein (StAR) (Gunnarsson et al. 2004) and to cause a decrease in growth hormone levels in rats (Lafuente et al. 2001) and to cause, in vitro in human cells, a decrease in the number of estrogen receptors (Garcia-Morales et al.1994). Cadmium can also activate the estrogen receptor alpha (Stoica et al. 2000) and, in view of the stimulation of lipid mobilization and lipolysis known to be induced by sex hormones 
(Hackney et al 2000), this xeno-estrogenic activity might contribute to the negative association with BMI observed for girls, men and women, whereas the fact that cadmium is associated with lower testosterone levels in boys might explain the absence, after adjustment for concurrent exposures, of a significant negative association in boys. That all observed effects were more pronounced at exposure values below the median than at higher exposures, is certainly compatible with a receptor mediated mechanism (see below).

HCB serum levels showed a positive association with height in boys. This increase in height might result from the higher sex hormone levels and the inhibition of aromatase which we found in association with higher HCB serum levels in the boys participating in this study (Dhooge et al, 2009). Inhibition of aromatase has been used to stimulate growth in short boys (Hero et al., 2005).

Urinary 1-OHP concentration showed a negative association with height in boys. That the negative association with height persisted after additional correction for urinary creatinine suggests that this association was not simply due to higher creatinine levels in adolescents of greater height. Our findings are consistent with the negative association reported for prenatal exposure to polycyclic aromatic hydrocarbons and growth (Choi et al., 2006; Tang et al., 2006) and with the reported effect of polycyclic aromatic hydrocarbons on cells of the skeletal system, adversely affecting growth (Holz et al., 2007).

That, in contrast with the observations for adolescents, we found no significant associations between internal exposure to pollutants and height in adults aged 50-65, suggests that the concentrations of pollutants measured in adults at the time of the study showed not enough correlation with the internal concentrations that prevailed when these subjects were growing as children or adolescents.

The negative association observed between BMI and blood lead concentration for adult women aged 50-65 might be due in part to the xeno-oestrogenic activity of lead 
described by Martin et al.(2003), but a more general toxic effect of lead (Doumouchtsis et al. 2009) might also play a role.

We have only a limited understanding of how the organochlorines measured in our study might affect BMI. That different mechanism predominate in adults compared to adolescents seems likely The quite strong negative associations in adolescents between organochlorines and BMI observed previously by Nawrot et al. (2002) and, for organochlorines other than PCB118, also in this study, are contrasting with the positive associations with BMI found for HCB, PCB 118 and p,p'-DDE in both adult men and women and, for men, also for dioxin-like activity. The negative associations observed in adolescents can probably be explained partly by a transient dilution effect in adipose tissue during growth as proposed by Nawrot et al. (2002). However, a dilution effect cannot explain the positive associations observed in adolescents between PCB118 and BMI after adjustment for other exposures, nor why the association between BMI and organochlorine pollutants was in all cases stronger at exposures below the median than at exposures above the median. That we observed, per unit of exposure, more pronounced effects at exposures below the median could be consistent with the hypothesis that the effects of organochlorines on body size are hormone- or receptor dependent, as receptor binding substances can be expected to show Michaelis-Menten kinetics and thus relatively stronger effects at low doses (Castano et al., 2008). In adults a higher consumption of animal fat over a long period of time might lead to higher serum levels of HCB, p,p'-DDE, PCB118 and dioxin-like activity in persons with a higher BMI. The effects of the endocrine disrupting pollutants depend probably on the one hand on changes induced in the production or metabolism of endogenous hormones, resulting in changed levels in the target tissues, and, on the other, on the direct interaction of the pollutants with the hormonal receptors. Differing interactions with aryl hydrocarbon (AhR) and hormonal receptors and levels of endogenous hormones 
might be responsible, at least in part, for the differences observed between the different pollutants in their association with BMI and for some of the differences between adults and adolescents as to associations with BMI.

Serum level of PCB118, a marker for total dioxin-like PCB concentration in human serum (Park et al., 2007), showed a positive association with BMI as well in boys as in girls and in both adult men and women, and a trend towards a positive relationship with length in boys. The positive association with height in boys was not affected by correction for sexual maturation and persisted partly after correction for levels of testosterone, suggesting that this association was not solely due to effects on hormone levels and/or sexual maturation. Our findings concerning PCB118 and BMI are consistent with the increase in BMI reported in several studies to be associated with increasing internal exposure to dioxins (Collins et al. 2007). Possibly PCB118 and other dioxin-like PCBs binding on the AHR receptor have a growth stimulating effect (Vondracek et al., 2005). The dioxin-like PCB77 induced adipocyte differentiation and promoted obesity and atherosclerosis in mice (Arsenescu et al. 2008). Dioxins can show anti-oestrogenic activity (Kietz et al, 2004), and such an effect might contribute to a positive association with BMI .

PCBs have xeno-estrogenic activity, mainly through their hydroxylated metabolites (Waller et al., 1995; Arulmozhiraja et al. 2005), and can also have estrogenic effects by inhibiting the metabolism of endogenous oestradiol (Kester et al. 2002). In the boys participating in this study (Dhooge et al., 2009), serum concentrations of marker PCBs showed a positive association with serum levels of endogenous sex hormones. The oestrogenic effects of PCBs might, through stimulation of lipid mobilization and lipolysis known to be caused by sex hormones (Hackney et al. 2000), explain the strong negative associations with BMI for both male and female adolescents, and also for female adults. For 
male adults too a negative association was observed between PCB levels and BMI, that was however only significant after correction for concurrent exposures.

In adolescents, the observed association of $\mathrm{HCB}$ with higher sex hormone levels (Dhooghe et al., 2009) might be the dominant effect in adolescents and might cause the quite strong negative association between HCB serum level and BMI, whereas the antiandrogenic characteristics of p,p'-DDE (Kelce et al. 1995; Li et al. 2008) and the antiandrogenic and anti-oestrogenic characteristics of HCB (Li et al. 2008) might be dominant mechanisms in adults, causing the (for HCB strong) positive association with BMI. That HCB might in addition induce a slightly hypothyroidal status (Foster et al., 1993; Meeker et al. 2007) might contribute to a positive association with BMI as a significant negative association between serum HCB concentration and free triiodothyronine was indeed observed in the adolescents participating in this study (unpublished results). 


\section{Conclusion}

Environmental exposures to pollutants resulting in "normal" levels of internal exposure were associated with small differences in height of adolescents and, particularly concerning organochlorines, with quite substantial differences in body mass index of both adolescents and adults. Associations between biological effects and internal exposures were, in terms of the regression coefficient, often stronger at exposures below the median and can probably, at least in part, be explained by endocrine disrupting effects. 


\section{Ackowledgements.}

We thank Marc Elskens and Tim Nawrot (statistics) and Hans Keune and Ilse Loots (communication) for advice. We gratefully acknowledge the collaboration of the 42 Flemish schools, the (psycho-medical) centres for guidance of pupils, all participating adolescents and their parents. 


\section{References}

Alvarez L, Randi A, Alvarez P, Piroli G, Chamson-Reig A, Lux-Lantos V, Kleiman de P D. Reproductive effects of hexachlorobenzene in female rats. J Appl Toxicol 2000;20:8187.

Arsenescu V, Arsenescu R I, King V, Swanson H, Cassis L A. Polychlorinated biphenyl-77 induces adipocyte differentiation and proinflammatory adipokines and promotes obesity and atherosclerosis. Environ Health Perspect 2008;116:761-768.

Arulmozhiraja S, Shiraishi F, Okumura T, Iida M, Takigami H, Edmonds J S, Morita M. Structural requirements for the interaction of 91 hydroxylated polychlorinated biphenyls with estrogen and thyroid hormone receptors. Toxicol Sci 2005;84:49-62.

Bilau M, Matthys C, Baeyens W, Bruckers L, De B G, Den H E, Keune H, Koppen G, Nelen V, Schoeters G, Van L N, Willems J L, De H S. Dietary exposure to dioxin-like compounds in three age groups: results from the Flemish environment and health study. Chemosphere 2008;70:584-592.

Bonefeld-Jorgensen E C, Andersen H R, Rasmussen T H, Vinggaard A M. Effect of highly bioaccumulated polychlorinated biphenyl congeners on estrogen and androgen receptor activity. Toxicology 2001;158:141-153.

Castano E, Flores-Saaib R D. A mathematical approach for the transactivation of hERalpha. Philos Transact A Math Phys Eng Sci 2008;366:2253-63. 
Choi H, Jedrychowski W, Spengler J, Camann D E, Whyatt R M, Rauh V, Tsai W Y, Perera F P. International studies of prenatal exposure to polycyclic aromatic hydrocarbons and fetal growth. Environ Health Perspect 2006;114:1744-1750.

Collins J J, Bodner K, Burns C J, Budinsky R A, Lamparski L L, Wilken M, Martin G D, Carson M L. Body mass index and serum chlorinated dibenzo-p-dioxin and dibenzofuran levels. Chemosphere 2007;66:1079-1085.

Covaci A, Voorspoels S, Thomsen C, van B B, Neels H. Evaluation of total lipids using enzymatic methods for the normalization of persistent organic pollutant levels in serum. Sci Total Environ 2006;366:361-366.

Croes K, Baeyens W, Bruckers L, Den H E, Koppen G, Nelen V, Van De M E, Keune H, Dhooge W, Schoeters G, Van Larebeke N. Hormone levels and sexual development in Flemish adolescents residing in areas differing in pollution pressure. Int $\mathrm{J}$ Hyg Environ Health 2009. In press. Available online 9 July 2009.

De Coster S, Koppen G, Bracke M, Schroijen C, Den H E, Nelen V, Van De M E, Bruckers L, Bilau M, Baeyens W, Schoeters G, Van Larebeke N. Pollutant effects on genotoxic parameters and tumor-associated protein levels in adults: a cross sectional study. Environ Health $2008 ; 7: 26$.

Dhooge W, Den Hond E, Koppen G, Bruckers L, Nelen V, Van De Mieroop E, Bilau M, Croes K, Baeyens W, Schoeters G, Van Larebeke N. Internal exposure to pollutants and sex hormone levels in Flemish male adolescents in a cross-sectional study: associations and dose-response relationships. Journal of Exposure Science and Environmental Epidemiology 2009, in press. 
Doumouchtsis K K, Doumouchtsis S K, Doumouchtsis E K, Perrea D N. The effect of lead intoxication on endocrine functions. J Endocrinol Invest 2009;32:175-183.

Foster W G, McMahon A, Younglai E V, Jarrell J F, Lecavalier P. Alterations in circulating ovarian steroids in hexachlorobenzene-exposed monkeys. Reprod Toxicol 1995;9:541548.

Foster W G, Pentick J A, McMahon A, Lecavalier P R. Body distribution and endocrine toxicity of hexachlorobenzene (HCB) in the female rat. J Appl Toxicol 1993;13:79-83.

Garcia-Morales P, Saceda M, Kenney N, Kim N, Salomon D S, Gottardis M M, Solomon H B, Sholler P F, Jordan V C, Martin M B. Effect of cadmium on estrogen receptor levels and estrogen-induced responses in human breast cancer cells. J Biol Chem 1994;269:16896-16901.

Gunnarsson D, Svensson M, Selstam G, Nordberg G. Pronounced induction of testicular PGF(2 alpha) and suppression of testosterone by cadmium-prevention by zinc. Toxicology 2004;200:49-58.

Hackney A C, Muoio D, Meyer W R. The Effect of sex steroid hormones on substrate oxidation during prolonged submaximal exercise in women. Jpn J Physiol 2000;50:489494.

Hero M, Norjavaara E, Dunkel L. Inhibition of estrogen biosynthesis with a potent aromatase inhibitor increases predicted adult height in boys with idiopathic short stature: a randomized controlled trial. J Clin Endocrinol Metab 2005;90:6396-6402. 
Hilscherova K, Dusek L, Kannan K, Giesy J P, Holoubek I. Evaluation of cytotoxicity, dioxin-like activity and estrogenicity of complex environmental mixtures. Cent Eur J Public Health 2000;8 Suppl:28-29.

Holz J D, Sheu T J, Drissi H, Matsuzawa M, Zuscik M J, Puzas J E. Environmental agents affect skeletal growth and development. Birth Defects Res C Embryo Today 2007;81:4150.

Kelce W R, Stone C R, Laws S C, Gray L E, Kemppainen J A, Wilson E M. Persistent DDT metabolite p,p'-DDE is a potent androgen receptor antagonist. Nature 1995;375:581-585.

Kester M H, Bulduk S, van T H, Tibboel D, Meinl W, Glatt H, Falany C N, Coughtrie M W, Schuur A G, Brouwer A, Visser T J. Potent inhibition of estrogen sulfotransferase by hydroxylated metabolites of polyhalogenated aromatic hydrocarbons reveals alternative mechanism for estrogenic activity of endocrine disrupters. J Clin Endocrinol Metab 2002;87:1142-1150.

Kietz S, Thomsen J S, Matthews J, Pettersson K, Strom A, Gustafsson J A. The Ah receptor inhibits estrogen-induced estrogen receptor beta in breast cancer cells. Biochem Biophys Res Commun 2004;320:76-82.

Lafuente A, Marquez N, Pazo D, Esquifino A I. Cadmium effects on dopamine turnover and plasma levels of prolactin, GH and ACTH. J Physiol Biochem 2001;57:231-236.

Li J, Li N, Ma M, Giesy JP, Wang Z. In vitro profiling of the endocrine disrupting potency of organochlorine pesticides. Toxicol Lett 2008;183:65-71.

Marshall W A, Tanner J M. Variations in pattern of pubertal changes in girls. Arch Dis Child 1969;44:291-303. 
Marshall W A, Tanner J M. Variations in the pattern of pubertal changes in boys. Arch Dis Child 1970;45:13-23.

Martin M B, Reiter R, Pham T, Avellanet Y R, Camara J, Lahm M, Pentecost E, Pratap K, Gilmore B A, Divekar S, Dagata R S, Bull J L, Stoica A. Estrogen-like activity of metals in MCF-7 breast cancer cells. Endocrinology 2003;144:2425-2436.

Martin M B, Voeller H J, Gelmann E P, Lu J, Stoica E G, Hebert E J, Reiter R, Singh B, Danielsen M, Pentecost E, Stoica A. Role of cadmium in the regulation of AR gene expression and activity. Endocrinology 2002;143:263-275.

Meeker J D, Altshul L, Hauser R. Serum PCBs, p,p'-DDE and HCB predict thyroid hormone levels in men. Environ Res 2007;104:296-304.

Nawrot T S, Staessen J A, Den Hond E M, Koppen G, Schoeters G, Fagard R, Thijs L, Winneke G, Roels H A. Host and environmental determinants of polychlorinated aromatic hydrocarbons in serum of adolescents. Environ Health Perspect 2002;110:583589.

Park H, Lee S J, Kang J H, Chang Y S. Congener-specific approach to human PCB concentrations by serum analysis. Chemosphere 2007;68:1699-1706.

Schroijen C, Baeyens W, Schoeters G, Den H E, Koppen G, Bruckers L, Nelen V, Van De M E, Bilau M, Covaci A, Keune H, Loots I, Kleinjans J, Dhooge W, Van L N. Internal exposure to pollutants measured in blood and urine of Flemish adolescents in function of area of residence. Chemosphere 2008;71:1317-1325.

Schroijen C, Van Wouwe W, Sanctorum H, Goeyens L., Baeyens W: CALUX analysis in small amounts of human serum. Organohalogen Compounds 2006;68:2511-2514. 
Selevan S G, Rice D C, Hogan K A, Euling S Y, Pfahles-Hutchens A, Bethel J. Blood lead concentration and delayed puberty in girls. N Engl J Med 2003;348:1527-1536.

Sheehan D M, Willingham E, Gaylor D, Bergeron J M, Crews D. No threshold dose for estradiol-induced sex reversal of turtle embryos: how little is too much? Environ Health Perspect 1999;107:155-159.

Steinberger A, Klinefelter G. Sensitivity of Sertoli and Leydig cells to xenobiotics in in vitro models. Reprod Toxicol 1993;7 Suppl 1:23-37.

Stoica A, Katzenellenbogen B S, Martin M B. Activation of estrogen receptor-alpha by the heavy metal cadmium. Mol Endocrinol 2000;14:545-553.

Tang D, Li T Y, Liu J J, Chen Y H, Qu L, Perera F. PAH-DNA adducts in cord blood and fetal and child development in a Chinese cohort. Environ Health Perspect 2006;114:1297-1300.

Van Wouwe N, Eppe G, Xhrouet C, Windal I, Vanderperren H, Debacker N, Sasse A, Baeyens W, De Pauw E, Sartor F et al. Validation of the CALUX bioassay for PCDD/F analyses in human blood plasma and comparison with GC-HRMS. Talanta 2004;63:1157-1167.

Vondracek J, Machala M, Bryja V, Chramostova K, Krcmar P, Dietrich C, Hampl A, Kozubik A. Aryl hydrocarbon receptor-activating polychlorinated biphenyls and their hydroxylated metabolites induce cell proliferation in contact-inhibited rat liver epithelial cells. Toxicol Sci 2005;83:53-63. 
Waller CL, Minor DL, McKinney JD. Using three-dimensional quantitative structureactivity relationships to examine estrogen receptor binding affinities of polychlorinated hydroxybiphenyls. Environ Health Perspect 1995;103:702-707. 
Tables

Table 1a

Adolescents. Characteristics and food intake by sex

\begin{tabular}{lll}
\hline & Boys (n=887) & Girls (n=792) \\
\hline Age (year) & $14.8(14.3-15.7)$ & $14.9(14.3-15.6)$ \\
Height $(\mathrm{cm})$ & $171(159-180)$ & $164(157-172)$ \\
BMI (kg/m²) & $19.8(17.3-23.9)$ & $20.4(17.3-24.8)$ \\
Food and nutrient intake: & & \\
fresh fruit and vegetables (g/day) & $238(76-549)$ & $270(89-591)$ \\
cereals (g/day) & $168(76-313)$ & $138(60-242)$ \\
fish (g/day) & $14.6(2.5-40.6)$ & $14.1(1.4-35.6)$ \\
dairy products (g/day) & $262(67-593)$ & $185(57-464)$ \\
meat (g/day) & $111(44-196)$ & $90(31-171)$ \\
animal fat (g/day) & $30.3(16.6-58.6)$ & $23.6(12.6-46.0)$ \\
\hline
\end{tabular}

Data are medians $\left(10^{\text {th }}\right.$ percentile $-90^{\text {th }}$ percentile $)$. 
Table 1b

Adults. Characteristics and food intake by sex

\begin{tabular}{|l|l|l|}
\hline & Men $(\mathrm{n}=775)$ & Women $(\mathrm{n}=808)$ \\
\hline Age (year) & $58.5(51.9-63.4)$ & $57.1(51.4-62.5)$ \\
\hline Height $(\mathrm{cm})$ & $175.0(166-180)$ & $162(154-170)$ \\
\hline BMI $\left(\mathrm{kg} / \mathrm{m}^{2}\right)$ & $27.0(23.1-31.9)$ & $25.7(21.4-32.8)$ \\
\hline Alcohol intake (glasses/week) & $10(4-27)$ & $7(2-16)$ \\
\hline Smokers: cigarettes/day & $20(5-30)$ & $15(4-27)$ \\
\hline Total fat consumption g/day & $58.0(31.5-101.2)$ & $45.5(24.1-77.4)$ \\
\hline Animal fat consumption g/day & $24.6(12.2-49.7)$ & $19.2(9.5-38.9)$ \\
\hline Green Vegetables g/day & $72(29-134)$ & $72(34-143)$ \\
\hline Other vegetables g/day & $87(27-218)$ & $101(39-250)$ \\
\hline Fresh Fruit g/day & $104(12-301)$ & $127(22-334)$ \\
\hline Cereals g/day & $160(64-284)$ & $152-205)$ \\
\hline Fish g/day & $25.6(7.6-63.1)$ & \\
\hline Meat g/day & $96(39-176)$ & \\
\hline Data & & \\
\hline
\end{tabular}

Data are medians $\left(10^{\text {th }}\right.$ percentile $-90^{\text {th }}$ percentile $)$. 


\section{Table 2}

Internal exposure to pollutants in boys and girls.

\begin{tabular}{|c|c|c|}
\hline & Boys $(n=887)$ & Girls $(n=792)$ \\
\hline Blood cadmium $(\mu \mathrm{g} / \mathrm{L})$ & $0.387(0.045-1.270)$ & $0.386(0.045-1.243)$ \\
\hline Blood lead $(\mu \mathrm{g} / \mathrm{L})$ & $25.0(12.0-51.2)$ & $18.1(8.8-38.1)$ \\
\hline Urinary cadmium ( $\mu \mathrm{g} / \mathrm{g}$ creatinine) & $0.199(0.115-0.352)$ & $0.192(0.112-0.376)$ \\
\hline Hexachlorobenzene (HCB) in serum (ng/g fat) & $22.8(15.2-34.5)$ & $18.3(12.3-26.6)$ \\
\hline $\mathrm{p}, \mathrm{p}$-DDE in serum (ng/g fat) & $103.6(46.8-403.9)$ & $84.0(39.3-247.1)$ \\
\hline Sum of marker PCBs in serum $(\mathrm{ng} / \mathrm{g} \text { fat })^{\mathrm{a}}$ & $79.8(42.7-141.3)$ & $53.1(30.3-98.5)$ \\
\hline PCB118 in serum (ng/g fat) & $7.28(2.85-13.58)$ & $6.00(2.37-11.59)$ \\
\hline Urinary 1 - OHP ( $\mu \mathrm{g} / \mathrm{g}$ creatinine) & $0.088(0.019-0.463)$ & $0.079(0.018-0.285)$ \\
\hline Urinary t,t'-MA (mg/g creatinine) & $0.084(0.013-0.243)$ & $0.090(0.016-0.285)$ \\
\hline
\end{tabular}

Data are medians $\left(10^{\text {th }}\right.$ percentile $-90^{\text {th }}$ percentile $)$.

${ }^{a}$ Sum of marker PCBs: sum of PCB congeners 138, 153 and 180 
Table 3

Internal exposure to pollutants in men and women

\begin{tabular}{lcc}
\hline & Men $(\mathbf{n}=\mathbf{7 7 5})$ & Women(n = 808) \\
\hline Blood cadmium $(\mu \mathrm{g} / \mathrm{L})$ & $0.44(0.13-1.11$ & $0.51(0.19-1.29)$ \\
Blood lead $(\mu \mathrm{g} / \mathrm{L})$ & $40.7(22.1-77.8)$ & $37.6(18.6-74.4)$ \\
Urinary cadmium $(\mu \mathrm{g} / \mathrm{g}$ creatinine $)$ & $0.50(0.30-1.10$ & $0.70(0.40-1.50)$ \\
Hexachlorobenzene (HCB) in serum (ng/g fat) & $44.2(23.7-90.9)$ & $71.9(36.2-143.3)$ \\
p,p'-DDE in serum (ng/g fat) & $443(123-1,398)$ & $556(167-1,818)$ \\
Sum of marker PCBs in serum (ng/g fat) ${ }^{\mathrm{a}}$ & $354(222-552)$ & $335(203-521)$ \\
PCB118 in serum (ng/g fat) & $22.8(10.4-46.8)$ & $28.8(12.9-52.9)$ \\
Urinary 1 - OHP ( $\mu \mathrm{g} / \mathrm{g}$ creatinine) & $0.135(0.024-0.588)$ & $0.147(0.041-0.730)$ \\
Urinary t,t'-MA (mg/g creatinine) & $0.315(0.116-0.957)$ & $0.554(0.167-1.794)$ \\
\hline
\end{tabular}

Data are medians $\left(10^{\text {th }}\right.$ percentile $-90^{\text {th }}$ percentile $)$.

${ }^{\mathrm{a}}$ Sum of marker PCBs: sum of PCB congeners 138, 153 and 180 
Table 4

Adolescents: association of height and BMI with internal exposure

\begin{tabular}{|c|c|c|c|c|c|}
\hline \multirow[t]{2}{*}{ Height or BMI } & \multirow[t]{2}{*}{$\begin{array}{l}\text { Exposure } \\
\text { marker }\end{array}$} & \multicolumn{2}{|c|}{$\begin{array}{l}\text { Boys. Multiple regression with all } \\
\text { confounders and significant covariates. }\end{array}$} & \multicolumn{2}{|c|}{$\begin{array}{l}\text { Boys. Forward stepwise multiple regression } \\
\text { starting with all confounders significant } \\
\text { covariates and significant internal exposures }\end{array}$} \\
\hline & & $\begin{array}{l}\text { Change (95\% CI) in height or } \\
\text { BMI for a doubling of exposure }\end{array}$ & $\mathbf{p}$ & $\begin{array}{l}\text { Change }(95 \% \mathrm{CI}) \text { in height or } \\
\text { BMI for a doubling of } \\
\text { exposure }\end{array}$ & $\mathbf{p}$ \\
\hline Height $(\mathrm{cm})^{\mathrm{a}}$ & $\begin{array}{l}\text { urinary cadmium } \\
(\mu \mathrm{g} / \mathrm{g} \text { creatinine })^{\mathrm{e}}\end{array}$ & $-1.09(-0.41 /-1.76) \mathrm{cm}$ & 0.0016 & $-1.18(-0.48 /-1.87) \mathrm{cm}$ & 0.0009 \\
\hline Height $(\mathrm{cm})^{\mathrm{a}}$ & $\mathrm{HCB}(\text { ng/g fat })^{\mathrm{e}}$ & $+1.26(+0.17 /+2.35) \mathrm{cm}$ & 0.024 & $+1.30(+0.20 /+2.39) \mathrm{cm}$ & 0.020 \\
\hline Height $(\mathrm{cm}) \mathrm{a}$ & $\begin{array}{l}\text { Urinary 1-OHP } \\
(\mu \mathrm{g} / \mathrm{g} \text { creatinin })^{\mathrm{e}}\end{array}$ & $-0.33(-0.03 /-0.64) \mathrm{cm}$ & 0.033 & $-0.32(-0.01 /-0.63) \mathrm{cm}$ & 0.042 \\
\hline Height $(\mathrm{cm})^{\mathrm{a}}$ & PCB118 (ng/g & $+0.73(+0.12 /+1.34) \mathrm{cm}$ & 0.019 & $+0.32(-0.37 /+1.01) \mathrm{cm}$ & 0.37 \\
\hline
\end{tabular}




\begin{tabular}{|c|c|c|c|c|c|}
\hline & fat $)^{e}$ & & & & \\
\hline $\mathrm{BMI}^{\mathrm{b}}$ & $\begin{array}{l}\text { urinary cadmium } \\
(\mu \mathrm{g} / \mathrm{g} \text { creatinine })^{\mathrm{e}}\end{array}$ & $-0.42(-0.13 /-0.71)$ & 0.0040 & $-0.18(+0.08 /-0.44)$ & 0.18 \\
\hline $\mathrm{BMI}^{\mathrm{b}}$ & $\mathrm{HCB}(\mathrm{ng} / \mathrm{g} \text { fat })^{\mathrm{e}}$ & $-2.27(-1.83 /-2.71)$ & $<0.000001$ & $-0.69(-0.20 /-1.18)$ & 0.0059 \\
\hline $\mathrm{BMI}^{\mathrm{b}}$ & $\begin{array}{l}\text { marker PCBs } \\
(\mathrm{ng} / \mathrm{g} \text { fat })^{\mathrm{e}}\end{array}$ & $-2.20(-1.94 /-2.46)$ & $<0.000001$ & $-2.45(-2.07 /-2.82)$ & $<0.000001$ \\
\hline $\mathrm{BMI}^{\mathrm{b}}$ & $\begin{array}{l}\text { PCB118 (ng/g } \\
\text { fat })^{\mathrm{e}}\end{array}$ & $-0.76(-0.51 /-1.02)$ & $<0.000001$ & $+0.56(+0.27 /+0.85)$ & 0.00015 \\
\hline & & \multicolumn{2}{|c|}{$\begin{array}{l}\text { Girls. Multiple regression with all } \\
\text { confounders and significant covariates. }\end{array}$} & \multicolumn{2}{|c|}{$\begin{array}{l}\text { Girls.Forward stepwise multiple regression } \\
\text { starting with all confounders significant } \\
\text { covariates and significant internal exposures. }\end{array}$} \\
\hline Height $(\mathrm{cm})^{\mathrm{c}}$ & $\begin{array}{l}\text { urinary cadmium } \\
(\mu \mathrm{g} / \mathrm{g} \text { creatinine })^{\mathrm{e}}\end{array}$ & $-0.61(-0.14 /-1.08) \mathrm{cm}$ & 0.012 & $-0.53(-0.05 /-1.01) \mathrm{cm}$ & 0.013 \\
\hline $\mathrm{BMI}^{\mathrm{d}}$ & $\begin{array}{l}\text { urinary cadmium } \\
(\mu \mathrm{g} / \mathrm{g} \text { creatinine })^{\mathrm{e}}\end{array}$ & $-0.47(-0.18 /-0.76)$ & 0.0016 & $-0.63(-0.34 /-0.92)$ & 0.000028 \\
\hline $\mathrm{BMI}^{\mathrm{d}}$ & $\mathrm{HCB}(\mathrm{ng} / \mathrm{g} \text { fat })^{\mathrm{e}}$ & $-1.64(-1.13 /-2.15)$ & $<0.000001$ & $-0.64(-0.03 /-1.25)$ & 0.041 \\
\hline
\end{tabular}




\begin{tabular}{|l|l|l|l||l|}
\hline & & & \\
& marker PCBs & $-1.73(-1.43 /-2.03)$ & $<0.000001$ & $-2.01(-1.62 /-2.41)$ \\
& $(\mathrm{ng} / \mathrm{g} \text { fat })^{\mathrm{e}}$ & & \\
\hline BMI $^{\mathrm{d}}$ & PCB118 (ng/g & $-0.38(-0.10 /-0.65)$ & 0.0081 & $+0.74(+0.41 /+1.07)$ \\
& fat $)^{\mathrm{e}}$ & & & \\
\hline
\end{tabular}

${ }^{a}$ Confounders and significant covariates comprised height of mother, height of father, age, smoking and use of alcohol; significant internal exposures comprised serum concentrations of marker PCBs, HCB and PCB118, and urinary concentrations of cadmium and 1-OHP.

${ }^{\mathrm{b}}$ Confounders and significant covariates comprised height of mother, height of father, age, parental education, smoking and use of alcohol; significant internal exposures comprised serum concentrations of marker PCBs, HCB, p,p'-DDE and PCB118, and urinary concentration of cadmium.

${ }^{\mathrm{c}}$ Confounders and significant covariates comprised height of mother, height of father, age, smoking and parental education; significant internal exposures comprised urinary concentrations of cadmium and 1-OHP.

${ }^{\mathrm{d}}$ Confounders and significant covariates comprised height of mother, height of father, age, smoking and parental education; significant internal exposures comprised serum concentrations of marker PCBs, HCB, p,p'-DDE and PCB118, blood concentration of lead and urinary concentrations of cadmium.

e $\ln$ transformed

${ }^{\mathrm{f}}$ The resulting models comprised, as independent variables for associations with height of boys: urinary concentration of cadmium and 1- hydroxypyrene, serum concentration of $\mathrm{HCB}$, age, height of mother, height of father and alcohol consumption; for associations with BMI of boys: urinary concentration of cadmium, serum concentration of marker PCBs, PCB118, p,p'-DDE and HCB, age, height of mother, height of father, smoking, parental education and 
alcohol consumption ; for associations with height of girls: urinary concentration of cadmium and 1- hydroxypyrene, age, height of mother, height of father and smoking; for associations with BMI of girls: urinary concentration of cadmium, serum concentration of marker PCBs, HCB and PCB118, age, height of mother, height of father and smoking. 


\section{Table 5}

Adolescents: Strength of association in function of intensity of internal exposure

\begin{tabular}{|c|c|c|c|c|}
\hline \multirow{3}{*}{$\begin{array}{l}\text { Body size } \\
\text { parameter }\end{array}$} & \multirow[t]{3}{*}{ Exposure marker } & \multicolumn{3}{|c|}{ Multiple regression with inclusion of confounders ${ }^{\mathrm{a}}$} \\
\hline & & \multicolumn{3}{|c|}{ Regression coefficient (Standard error of the mean) } \\
\hline & & $\begin{array}{l}\text { Boys with exposure } \\
\text { equal to or below } \\
\text { median }\end{array}$ & $\begin{array}{l}\text { Boys with exposure } \\
\text { above median }\end{array}$ & $\mathbf{p}^{\mathbf{b}}$ \\
\hline Height $(\mathrm{cm})$ & $\begin{array}{l}\text { urinary cadmium } \\
\text { ( } \mu \mathrm{g} / \mathrm{g} \text { creatinine) }\end{array}$ & $-9.73(9.64)$ & $-1.19(1.14)$ & 0.023 \\
\hline Height $(\mathrm{cm})$ & HCB (ng/g fat) & $-0.063(0.114)$ & $+0.081(0.050)$ & 0.51 \\
\hline Height $(\mathrm{cm})$ & $\begin{array}{l}\text { Urinary 1-OHP }(\mu \mathrm{g} / \mathrm{g} \\
\text { creatinin })\end{array}$ & $-27.8(14.7)$ & $-1.7(0.9)$ & 0.19 \\
\hline Height $(\mathrm{cm})$ & PCB118 (ng/g fat) & $+0.437(0.210)$ & $+0.062(0.051)$ & 0.19 \\
\hline BMI & $\begin{array}{l}\text { urinary cadmium } \\
(\mu \mathrm{g} / \mathrm{g} \text { creatinine })\end{array}$ & $-7.05(4.70)$ & $-0.96(0.42)$ & 0.087 \\
\hline BMI & HCB (ng/g fat) & $-0.356(0.051)$ & $+0.009(0.015)$ & $<0.000001$ \\
\hline \multirow[t]{2}{*}{ BMI } & $\begin{array}{l}\text { marker PCBs (ng/g } \\
\text { fat) }\end{array}$ & $-0.135(0.009)$ & $-0.005(0.002)$ & $<0.000001$ \\
\hline & & $\begin{array}{l}\text { Girls with exposure } \\
\text { equal to or below } \\
\text { median }\end{array}$ & $\begin{array}{l}\text { Girls with exposure } \\
\text { above median }\end{array}$ & $\mathrm{p}$ \\
\hline Height $(\mathrm{cm})$ & $\begin{array}{l}\text { urinary cadmium } \\
(\mu \mathrm{g} / \mathrm{g} \text { creatinine })\end{array}$ & $-1.28(7.52)$ & $+0.05(0.50)$ & 0.0066 \\
\hline BMI & $\begin{array}{l}\text { urinary cadmium } \\
(\mu \mathrm{g} / \mathrm{g} \text { creatinine })\end{array}$ & $-13.04(4.94)$ & $-0.06(0.30)$ & 0.00097 \\
\hline
\end{tabular}




\begin{tabular}{|l|l|l|l|l|}
\hline BMI & HCB (ng/g fat) & $-0.348(0.070)$ & $-0.062(0.027)$ & 0.00016 \\
\hline BMI & marker PCBs (ng/g & $-0.139(0.016)$ & $-0.004(0.003)$ & $<0.000001$ \\
& fat) & & & \\
\hline
\end{tabular}

${ }^{\mathrm{a}}$ As indicated under methods.

${ }^{\mathrm{b}}$ Calculated as described under methods. 


\section{Table 6}

Adults. Association of BMI with internal exposure

\begin{tabular}{|c|c|c|c|c|}
\hline \multirow[t]{2}{*}{$\begin{array}{l}\text { Exposure } \\
\text { marker }\end{array}$} & \multicolumn{2}{|c|}{$\begin{array}{l}\text { Male adults. Multiple regression with } \\
\text { confounders and significant covariates }{ }^{\text {a }} \text {. }\end{array}$} & \multicolumn{2}{|c|}{$\begin{array}{l}\text { Male adults. Forward stepwise multiple } \\
\text { regression starting with all confounders } \\
\text { significant covariates and significant internal } \\
\text { exposures }{ }^{\mathrm{b}} \text {. }\end{array}$} \\
\hline & $\begin{array}{l}\text { Change }(95 \% \mathrm{CI}) \text { in BMI for a } \\
\text { doubling of exposure }\end{array}$ & $\mathbf{p}$ & $\begin{array}{l}\text { Change }(95 \% \mathrm{CI}) \text { in height or } \\
\text { BMI for a doubling of } \\
\text { exposure }\end{array}$ & $\mathbf{p}$ \\
\hline $\begin{array}{l}\text { urinary cadmium } \\
(\mu \mathrm{g} / \mathrm{g} \text { creatinine })^{\mathrm{c}}\end{array}$ & $-0.384(-0.021 /-0.746)$ & 0.038 & $-0.210(+0.105 /-0.524)$ & 0.19 \\
\hline $\mathrm{HCB}(\mathrm{ng} / \mathrm{g} \text { fat })^{\mathrm{c}}$ & $+1.586(+1.267 /+1.906)$ & $<0.000001$ & $+1.642(+1.260 /+2.024)$ & $<0.000001$ \\
\hline $\begin{array}{l}\mathrm{p}, \mathrm{p}^{\prime}-\mathrm{DDE}(\mathrm{ng} / \mathrm{g} \\
\mathrm{fat})^{\mathrm{c}}\end{array}$ & $+0.559(+0.387 /+0.731)$ & $<0.000001$ & $+0.609(+0.404 /+0.815)$ & $<0.000001$ \\
\hline $\begin{array}{l}\text { PCB118 (ng/g } \\
\text { fat })^{\mathrm{c}}\end{array}$ & $+0.789(+0.494 /+1.083)$ & $<0.000001$ & $+0.824(0.463 /+1.185)$ & 0.000009 \\
\hline
\end{tabular}




\begin{tabular}{|c|c|c|c|c|}
\hline 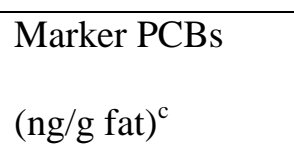 & $-0.198(+0.255 /-0.651)$ & 0.39 & $-3.201(-2.61 /-3.79)$ & $<0.000001$ \\
\hline \multirow[t]{2}{*}{$\begin{array}{l}\text { Dioxin fraction } \\
\text { of dioxin-like } \\
\text { activity TEQ } \\
(\mathrm{pg} / \mathrm{g} \text { fat })^{\mathrm{c}}\end{array}$} & $+0.369(+0.142+0.596)$ & 0.0015 & $+0.273(+0.071 /+0.476)$ & 0.0083 \\
\hline & \multicolumn{2}{|c|}{$\begin{array}{l}\text { Female adults. Multiple regression with } \\
\text { confounders and significant covariates }{ }^{d} \text {. }\end{array}$} & \multicolumn{2}{|c|}{$\begin{array}{l}\text { Female adults. Forward stepwise multiple } \\
\text { regression starting with all confounders } \\
\text { significant covariates and significant internal } \\
\text { exposures }^{\mathrm{e}} \text {. }\end{array}$} \\
\hline $\begin{array}{l}\text { urinary cadmium } \\
(\mu \mathrm{g} / \mathrm{g} \text { creatinine })^{\mathrm{c}}\end{array}$ & $-0.545(-0.123 /-0.967)$ & 0.011 & $-0.367(-0.012 /-0.721)$ & 0.043 \\
\hline HCB (ng/g fat $)^{c}$ & $+1.81(+1.38 /+2.24)$ & $<0.000001$ & $+2.73(+2.29 /+3.17)$ & $<0.000001$ \\
\hline 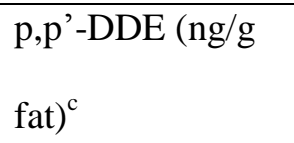 & $+0.304(+0.081 /+0.528)$ & 0.0077 & $+0.674(+0.445 /+0.902)$ & $<0.000001$ \\
\hline marker PCBs & $-2.11(-1.54 /-2.69)$ & $<0.000001$ & $-6.18(-5.48 /-6.87)$ & $<0.000001$ \\
\hline
\end{tabular}




\begin{tabular}{|l|l|l|l|l|}
\hline${ }^{(\mathrm{ng} / \mathrm{g} \text { fat })^{\mathrm{c}}}$ & & & & \\
\hline PCB118 $(\mathrm{ng} / \mathrm{g}$ & $+0.45(+0.06 /+0.85)$ & 0.025 & $+1.28(+0.83 /+1.72)$ & $<0.000001$ \\
${\text { fat })^{\mathrm{c}}}$ & & & & \\
\hline${\text { Lead }(\mu \mathrm{g} / \mathrm{L})^{\mathrm{c}}}$ & $-0.75(-0.31 /-1,18)$ & 0.00083 & $-0.21(+0.15 /-0,56)$ & 0.25 \\
\hline
\end{tabular}

${ }^{a}$ Confounders and significant covariates comprised age, smoking, alcohol consumption, "highest education in the family", consumption of vegetables and consumption of meat..

${ }^{\mathrm{b}}$ Confounders and significant covariates comprised age, smoking, alcohol consumption, "highest education in the family", consumption of vegetables and consumption of meat.. Significant internal exposures comprised serum concentrations of marker PCBs, PCB118, HCB and p,p'-DDE, dioxin-like activity of the serum dioxin fraction (TEQ) and urinary concentrations of cadmium and of hydroxypyrene. The resulting model comprised following parameters: serum concentrations of marker PCBs, PCB118, HCB and p,p'-DDE, dioxin-like activity of the serum dioxin fraction (TEQ), urinary concentration of cadmium, consumption of alcohol, meat and vegetables and "highest education in the family".

${ }^{c}$ In transformed

${ }^{\mathrm{d}}$ Confounders and significant covariates comprised age, alcohol consumption, "highest education in the family", consumption of vegetables and consumption of meat. Significant internal exposures comprised serum concentrations of marker PCBs, PCB118, HCB and p,p'-DDE, blood concentration of lead and urinary concentration of cadmium ,. 
${ }^{\mathrm{e}}$ Confounders and significant covariates comprised age, alcohol consumption, "highest education in the family", consumption of vegetables and consumption of meat. Significant internal exposures comprised serum concentrations of marker PCBs, PCB118, HCB and p,p'-DDE, blood concentration of lead and urinary concentration of cadmium. The resulting model comprised following parameters: serum concentrations of marker PCBs, PCB118, HCB and p,p'-DDE, urinary concentration of cadmium, consumption of alcohol, meat and vegetables; and "highest education in the family". 
Table 7

Adults: Strength of association of BMI with internal exposure in function of intensity of internal exposure

\begin{tabular}{|c|c|c|c|}
\hline \multirow[t]{3}{*}{ Exposure marker } & \multicolumn{3}{|c|}{ Multiple regression with inclusion of confounders ${ }^{\mathrm{a}}$} \\
\hline & \multicolumn{3}{|c|}{ Regression coefficient (Standard error of the mean) } \\
\hline & $\begin{array}{l}\text { Male adults with } \\
\text { exposure below } \\
\text { median }\end{array}$ & $\begin{array}{l}\text { Male adults with } \\
\text { exposure above } \\
\text { median }\end{array}$ & $\mathrm{p}^{\mathrm{b}}$ \\
\hline $\begin{array}{l}\text { urinary cadmium } \\
\text { ( } \mu \mathrm{g} / \mathrm{g} \text { creatinine) }\end{array}$ & -1.45 & -0.38 & 0.35 \\
\hline HCB (ng/g fat) & 0.097 & 0.026 & 0.000068 \\
\hline p,p'-DDE (ng/g fat) & 0.00442 & 0.00003 & 0.000001 \\
\hline PCB 118 (ng/g fat) & 0.117 & 0.006 & 0.00033 \\
\hline $\begin{array}{l}\text { marker PCBs (ng/g } \\
\text { fat) }\end{array}$ & -0.0162 & -0.0039 & 0.0031 \\
\hline \multirow[t]{2}{*}{$\begin{array}{l}\text { Dioxin fraction of } \\
\text { dioxin-like activity } \\
\text { TEQ (pg/g fat) }\end{array}$} & 0.0548 & -0.0055 & 0.0088 \\
\hline & $\begin{array}{l}\text { Female adults with } \\
\text { exposure below } \\
\text { median }\end{array}$ & $\begin{array}{l}\text { Female adults with } \\
\text { exposure above } \\
\text { median }\end{array}$ & $\mathrm{p}$ \\
\hline urinary cadmium & -0.54 & -0.60 & 0.99 \\
\hline
\end{tabular}




\begin{tabular}{|c|c|c|c|}
\hline ( $\mu \mathrm{g} / \mathrm{g}$ creatinine $)$ & & & \\
\hline HCB (ng/g fat) & 0.045 & 0.029 & 0.13 \\
\hline p,p'-DDE (ng/g fat) & 0.00075 & 0.00008 & 0.0071 \\
\hline $\begin{array}{l}\text { marker PCBs (ng/g } \\
\text { fat) }\end{array}$ & -0.0114 & -0.0075 & 0.29 \\
\hline PCB 118 (ng/g fat $)^{d}$ & 0.098 & 0.055 & 0.065 \\
\hline Lead $(\mu \mathrm{g} / \mathrm{L})$ & -0.084 & -0.011 & 0.024 \\
\hline
\end{tabular}

${ }^{\text {a }}$ As indicated under methods. Concerning marker PCBs for the men and PCB118 for the women significant concurrent exposures were also included in the multiple regressions, because of their important impact (see table 6) on the corresponding associations.

${ }^{\mathrm{b}}$ Calculated as described under methods

${ }^{\mathrm{c}}$ Concurrent exposures included in the multiple regressions were serum concentrations of PCB118, HCB and p,p'-DDE, the dioxin fraction of dioxin-like activity in blood plasma and urinary concentrations of cadmium and_1-OHP.

${ }^{\mathrm{d}}$ Concurrent exposures included in the multiple regressions were serum concentrations of marker PCBs, HCB and p,p'-DDE, blood concentration of lead and urinary concentration of cadmium. 